\title{
PENGGUNAAN PAKAN LENGKAP BERBASIS TEBON JAGUNG TERHADAP KECERNAAN SERAT KASAR DAN BAHAN EKSTRAK TANPA NITROGEN SAPI FRIES HOLLAND
}

\author{
Didin Binol, R. A. V. Tuturoong, S. A. E Moningkey, A. Rumambi
}

Fakultas Peternakan Universitas Sam Ratulangi, 95115

\begin{abstract}
ABSTRAK
Penelitian ini bertujuan untuk mengetahui penggunan pakan lengkap berbasis tebon jagung terhadap kecernaan serat kasar dan bahan ekstrak tanpa nitrogen (BETN) sapi perah Fries Holland (FH). Sapi perah FH yang digunakan berjumlah 14 ekor dengan umur 7 - 8 tahun dengan bobot badan $300-400 \mathrm{~kg}$. Penelitian ini menggunakan metode eksperimen dengan analisis uji $\mathrm{T}$ (keragaman yang tidak sama) terdiri atas 2 perlakuan dengan ulangan sebanyak 7 kali. Perlakuan tersebut adalah perbandingan antara tebon jagung dan rumput raja, yaitu $\mathrm{Ra}=$ tebon jagung $70 \%$ + konsentrat $30 \%$ dan $\mathrm{Rb}=$ tebon jagung $35 \%+$ rumput raja $35 \%+$ konsentrat $30 \%$. Variabel yang diamati adalah konsumsi serat kasar, konsumsi BETN, kecernaan serat kasar dan kecernaan BETN. Hasil analisis uji $\mathrm{T}$ menunjukan bahwa konsumsi serat kasar perlakuan $\mathrm{Ra}(2,07 \mathrm{~kg} / \mathrm{ekor} / \mathrm{hari})$ berbeda tidak nyata $(\mathrm{P}>0,05)$ dengan perlakuan $\mathrm{Rb}$ (2,10 kg/ekor/hari) sedangkan konsumsi BETN menunjukan berbeda tidak nyata $(\mathrm{P}>0,05)$ antara perlakuan $\mathrm{Ra}(3,36$ $\mathrm{kg} / \mathrm{ekor} / \mathrm{hari})$ dengan perlakuan $\mathrm{Rb}(3,46$ kg/ekor/hari). Kecernaan serat kasar berdasarkan hasil analisis uji $\mathrm{T}$ menunjukan berbeda sangat nyata $(\mathrm{P}<0,01)$ antara perlakuan $\mathrm{Ra}(70,31 \%)$ dengan perlakuan $\mathrm{Rb}(78,15)$ sedangkan kecernaan BETN menunjukan berbeda tidak nyata $(\mathrm{P}>0,05)$ antara perlakuan $\mathrm{Ra}(87,97 \%)$ dan perlakuan $\mathrm{Rb}(90,28 \%)$.
\end{abstract}

\footnotetext{
*Korespondensi (Corresponding author)

Email : ronny.tuturoong@yahoo.com
}

Berdasarkan hasil penelitian ini dapat disimpulkan bahwa pemberian pakan dengan perlakuan konsentrat $30 \%$, tebon jagung 35\%, rumput raja 35\% lebih baik dalam meningkatkan kecernaan serat kasar dibanding dengan pakan yang hanya terdiri dari konsentrat 30\%, tebon jagung 70\% pada sapi Fries Holland.

Kata Kunci: kecernaan, serat kasar, BETN, sapi Fries Holland.

\section{ABSTRACT}

THE USE OF A COMPLETE FEED BASED ON CORN FORAGE ON THE DIGESTIBILITY OF CRUDE FIBER AND NITROGEN FREE EXTRACT OF THE FRIES HOLLAND DAIRY COWS. This study aims to determine of the use of complete feed based on corn forage on the digestibility of crude fiber and nitrogen free-extract (NFE) of the Fries Holland (FH) dairy cows. This research used 14 dairy cows aged 7-8 years with a bodyweight of $300-400 \mathrm{~kg}$. This study used an experimental method with ttest analysis (unequal diversity) consisting of 2 treatments with 7 replications. This study was arranged in two treatment groups according to t-test (assuming unequal varience). They consisted of $\mathrm{Ra}=70 \%$ corn forage $+30 \%$ concentrate and $\mathrm{Rb}=35 \%$ corn forage $+35 \%$ king grass $+30 \%$ concentrate. The variables observed were crude fiber consumption, NFE consumption, crude fiber digestibility and NFE digestibility. $T$ Test analysis results showed that the consumption of crude fiber treatment of $\mathrm{Ra}(2.07 \mathrm{~kg} / \mathrm{head} /$ day $)$ was not 
significantly different $(\mathrm{P}>0.05)$ with $\mathrm{Rb}$ treatment $(2.10 \mathrm{~kg} / \mathrm{head} /$ day $)$ while NFE consumption showed no significant difference $(\mathrm{P}>0.05)$ between $\mathrm{Ra}$ (3.36 $\mathrm{kg} / \mathrm{head} /$ day) and $\mathrm{Rb}(3.46 \mathrm{~kg} / \mathrm{head} /$ day $)$. The digestibility of crude fiber showed a very significant difference $(\mathrm{P}<0.01)$ between $\mathrm{Ra}(70.31 \%)$ and $\mathrm{Rb}(78.15 \%)$ while NFE digestibility showed no significant difference $(\mathrm{P}>0.05)$ between $\mathrm{Ra}$ $(87.97 \%)$ and $\mathrm{Rb}(90.28 \%)$. Based on the results of this study it can be concluded that feeding with concentrate of $30 \%$, corn forage of $35 \%$ and king grass of $35 \%$ has better in increasing digestibility of crude fiber than just consisting of concentrate of $30 \%$ and corn forage of $70 \%$ in dairy cows (FH).

Keywords: digestibility, crude fiber, NFE, Fries Holland cows.

\section{PENDAHULUAN}

Sapi perah adalah salah satu ternak penghasil susu yang dikembangkan untuk memenuhi kebutuhan protein hewani, sehingga dalam pemeliharaanya selalu diarahkan pada peningkatan produksi susu. Sapi Fries Holland (FH) merupakan bangsa sapi perah yang memiliki produksi susu tinggi, dimana susu merupakan salah satu bahan pangan sumber protein hewani selain telur dan daging.

Di Indonesia produktivitas sapi FH masih rendah dengan populasi sapi perah 545 ekor dan produksi 920,1 ribu ton susu segar (Ditjen PKH, 2017). Dalam usaha untuk meningkatkan produksi susu dapat dilakukan dengan cara peningkatan populasi sapi perah, perbaikan tingkat kecernaan ternak melalui pemberian pakan, tatalaksana, serta efisiensi reproduksi yang baik.

Pakan sapi perah pada umumnya terdiri dari hijauan dan konsentrat. Namun ketersediaan pakan hijauan, terkadang menjadi kendala dalam pemeliharaan ternak ruminansia terutama hijauan segar khususnya di negara berkembang, karena suplai hijauan pakan ternak selalu mengalami kelangkaan dan berfluktuasi sepanjang tahun. Pemberian pakan hijauan belum mampu memenuhi kebutuhan ternak akan nutrisi sehingga perlu adanya penambahan konsentrat sebagai pakan pelengkap.

Tanaman jagung merupakan salah satu tanaman pangan yang sangat berguna bagi ternak karena hampir keseluruh bagian tanaman ini dapat dimanfaatkan. Keberadaan dari tanaman jagung sendiri diharapkan dapat menjadi solusi dari masalah kekurangan pakan ternak ruminansia khususnya pada musim kemarau. Tebon jagung adalah seluruh bagian tanaman termasuk batang, daun, dan buah muda yang umumnya dipanen pada umur tanaman 45-65 hari (Soeharsono dan Sudaryanto, 2006) dengan kandungan nutrisi yaitu protein kasar $12,06 \%$, serat kasar $25,2 \%$, kalsium $0,28 \%$ dan fosfor 0,23\% (Erna dan Sarjiman, 2007). Rumput raja (Pennisetum purpupoides) adalah salah 
satu sumber utama pakan hijauan yang potensial dan sering diberikan pada ternak ruminansia serta memiliki pertumbuhan yang sangat cepat dan produksi sangat tinggi. Kandungan nutrisi rumput raja terdiri dari protein kasar 13,05\%, TDN $57,50 \%$, kalsium $0,37 \%$, fosfor $0,39 \%$ (Sutardi, 1981), NDF 76,22\% dan ADF $46,75 \%$ (Siswanto et al., 2016). Penggunaan konsentrat dalam pakan ternak ruminansia dimaksudkan sebagai suplemen atau pakan lengkap dan lebih palatabel serta kaya akan karbohidrat dan protein.

Serat kasar adalah bagian dari karbohidrat struktural yang terdiri dari selulosa, hemiselulosa dan lignin (Tilman, et al., 1989). Menurut Sondakh et al. (2018), serat kasar digunakan oleh mikroorganisme rumen sebagai bahan makanan sumber energi yang kemudian nantinya akan diubah menjadi asam lemak terbang (VFA). Serat kasar dalam pakan yang dikonsumsi ternak juga dapat memberikan dampak negatif terhadap kecernaan jika tidak diperhatikan kuantitas dan kualitasnya. BETN merupakan golongan karbohidrat non-struktural yang mudah dicerna (Dewi et al., 2020). BETN terdiri dari gula, pati, pentose dan bahanbahan penyusun lainnya. Karbohidrat nonstruktural dapat ditemukan di dalam sel tanaman dan mempunyai kecernaan lebih tinggi dibandingkan dengan karbohidrat struktural. Tujuan penelitian ini adalah untuk mengetahui penggunaan pakan lengkap berbasis tebon jagung terhadap kecernaan serat kasar dan BETN sapi FH.

\section{MATERI DAN METODE PENELITIAN}

Penelitian ini dilaksanakan di Unit Pelaksana Teknis Daerah (UPTD) Pembibitan Ternak dan Hijauan Pakan Provinsi Sulawesi Utara Desa Tampusu, Kecamatan Remboken, Kabupaten Minahasa. Penelitian ini menggunakan 14 ekor ternak sapi perah FH dengan umur 7-8 tahun dengan bobot badan 300 - $400 \mathrm{~kg}$.

Kandang yang digunakan adalah kandang individual sebanyak 14 kandang yang dilengkapi dengan tempat pakan dan tempat minum. Perlengkapan lain yang digunakan dalam penelitian ini yaitu alat mencincang pakan (chopper), timbangan untuk menimbang feses, kantong plastik, skep mini untuk proses mengangkat feses dan alat tulis menulis.

Pakan yang digunakan dalam penelitian ini terdiri dari pakan hijauan (tebon jagung dan rumput raja) serta pakan pelengkap (konsentrat). Pakan konsentrat disusun dari bahan-bahan pakan yaitu jagung, dedak halus, bungkil kedelei, bungkil kelapa, tepung ikan, premix (suplemen, vitamin, mineral) dan garam. Penggunaan $30 \%$ untuk pakan konsentrat dan $70 \%$ pakan hijauan, didasarkan pada 
Tabel 1. Komposisi Nutrien Pakan Perlakuan

\begin{tabular}{lccc}
\hline \multirow{2}{*}{ Nutrien } & Konsentrat & Tebon Jagung* & Rumput Raja** \\
\cline { 2 - 4 } & \multicolumn{3}{c}{$\%$} \\
\hline Bahan Kering & 87,93 & 19,74 & 20,30 \\
Protein & 16,65 & 10,90 & 9,52 \\
Lemak Kasar & 10,75 & 2,17 & 3,14 \\
Serat Kasar & 11,23 & 33,21 & 31,26 \\
NDF & 27,23 & 69,81 & 73,52 \\
ADF & 14,39 & 40,20 & 44,49 \\
Kalsium & 0,73 & 0,39 & 0,35 \\
Fosfor & 1,82 & 0,23 & 0,28 \\
Abu & 9,11 & 7,67 & 9,38 \\
BETN & 40,48 & 46,05 & 44,98 \\
Energi Bruto (Kkal) & 3708,89 & $3791,00 *$ & 3375,00 \\
\hline
\end{tabular}

Keterangan : * Menurut Tulung et al. (2020)

** Lab. Minat Nutrisi dan Makanan Ternak Fak. Peternakan UB (2019)

Tabel 2. Formulasi dan Komposisi Nutrien Pakan Perlakuan

\begin{tabular}{lcc}
\hline \multicolumn{1}{c}{ Formulasi Pakan } & \multicolumn{2}{c}{ Perlakuan } \\
\cline { 2 - 3 } & $\mathrm{Ra}$ & $\mathrm{Rb}$ \\
\hline Konsentrat & 30 & 30 \\
Tebon Jagung & 70 & 35 \\
Rumput raja & 0 & 35 \\
Total & 100 & 100 \\
Komposisi Zat Makanan (\%) & & \\
Bahan Kering & 40,20 & 40,39 \\
Protein Kasar & 12,63 & 12,13 \\
Serat Kasar & 26,16 & 25,93 \\
Lemak Kasar & 4,74 & 5,08 \\
BETN & 44,38 & 44 \\
Energi Bruto (Kkal) & 3766,37 & 3620,77 \\
\hline Keterangan : Dihitur
\end{tabular}

Keterangan : Dihitung berdasarkan Tabel 1

pada kebutuhan ternak sapi perah dengan bobot badan rata-rata $300 \mathrm{~kg}$, dengan kebutuhan bahan kering 7,5 kg (NRC, 2001). Sehingga jumlah penggunaan konsentrat dalam pakan lengkap, baik pakan Ra maupun Rb adalah sebesar 30\% x $7,5 \mathrm{~kg}=2,25 \mathrm{~kg}$, dan bagian 50\% lainnya dipenuhi oleh rumput raja pada perlakuan $\mathrm{Ra}$ dan rumput

\section{Metode Penelitian}

Penelitian ini adalah penelitian dengan metode eksperimen yang terdiri dari 2 perlakuan masing-masing 7 ulangan. 
Perlakuan yang di terapkan adalah: $\mathrm{Ra}=$ $30 \%$ konsentrat $+70 \%$ tebon jagung $\mathrm{Rb}=$ $30 \%$ konsentrat $+35 \%$ rumput raja $+35 \%$ tebon jagung.

\section{Tatalaksana Penelitian}

Pelaksanaan penelitian ini dibagi menjadi 3 tahap yaitu tahap pendahuluan, tahap pra koleksi dan tahap koleksi.

1. Tahap Pendahuluan

Pada awal penelitian ternak diberikan kesempatan untuk beradaptasi dengan pakan perlakuan. Adaptasi pakan dilakukan selama 7 hari. Adaptasi dilakukan dengan tujuan untuk membiasakan ternak mengkonsumsi pakan perlakuan dan mengetahui jumlah konsumsi pakan yang diberikan secara ad libitum serta air minum disediakan setiap saat. Sebelum diberikan ke ternak, tebon jagung dan rumput raja dicacah (Chopper) terlebih dahulu dengan ukuran $\pm 5 \mathrm{~cm}$. Konsumsi ternak dihitung dari konsumsi bahan kering.

2. Tahap Pra-Koleksi

Pembatasan pemberian pakan sebanyak $80 \%$ dari rerata konsumsi pakan pada tahap pendahuluan dilakukan 3 hari sebelum koleksi dan pengambilan sampel. Pembatasan pakan dilakukan agar pakan yang diberikan dapat dikonsumsi secara keseluruhan dan tidak tersisa.

3. Tahap Koleksi

Pengukuran kecernaan ini berdasarkan metode koleksi total. Pada tahap ini, pakan tetap diberikan sebanyak $80 \%$. Pengumpulan feses dilakukan selama 5 hari begitu juga dengan pengambilan sampel pakan. Sampel feses diambil setiap ternak defikasi sebanyak 5\% kemudian dimasukan kedalam kantong plastik dan timbang untuk mendapatkan berat segar. Setiap kantong plastik diberikan identitas dan dilakukan pencatatan data feses yang diperoleh. Feses kemudian dikeringkan di bawah sinar matahari dan dilakukan penimbangan kembali untuk mendapatkan berat kering. Sampel hijauan diambil masing-masing sebanyak 5\% setelah itu dikeringkan oven dengan suhu $55^{\circ} \mathrm{C}$ untuk mendapatkan berat kering. Sampel yang sudah dikeringkan kemudian dikomposit dan diambil 100 gram untuk analisis proksimat di laboratorium.

\section{Variabel Yang Diamati}

\section{Konsumsi Serat Kasar}

Konsumsi serat kasar diperoleh dari selisih anatara serat kasar dalam pakan yang diberikan dengan serat kasar dalam pakan sisa

\section{Konsumsi BETN}

Konsumsi BETN diperoleh dari selisih anatara BETN dalam pakan yang diberikan dengan BETN dalam pakan sisa.

\section{Kecernaan Serat Kasar (KcSK)}

$$
\text { KcSK }=\frac{\text { SK Konsumsi }- \text { SK dari Feses }}{\text { SK Konsumsi }} \times 100 \%
$$




\section{Kecernaan BETN (KcBETN)}

KcBETN $=\frac{\text { BETN Konsumsi }- \text { BETN dari Feses }}{\text { BETN Konsumsi }} \times 100 \%$

\section{Analisis Data}

Penelitian ini dilakukan dengan menggunakan analisis uji $\mathrm{T}$ dua contoh dengan ragam tidak sama (t-Test two sample assuming unequal varience) (Snedecor dan Cochran, 1989; Derrick et al., 2017).

Rumus t-test : $\mathrm{t}=\frac{\bar{x}_{1-}-\bar{x}_{2}}{\sqrt{\frac{\sigma_{1}^{2}}{\mathrm{n}_{1}}+\frac{\sigma_{2}^{2}}{\mathrm{n}_{2}}}}$

dimana $: \mathrm{t}=\mathrm{t}$ statistik

$\bar{x}_{1}$ dan $\bar{x}_{2}=$ rataan hasil dari dua contoh perlakuan

$\sigma^{21}$ dan $\sigma^{2}{ }_{2}=$ keragaman dari hasil kedua contoh perlakuan

$\mathrm{n}_{1}$ dan $\mathrm{n}_{2}=$ jumlah pengamatan dari 2

perlakuan

$\mathrm{t}$ - statistik mengikuti suatu distribusi t, dengan perkiraan derajat bebas (df), sebagai berikut:

$$
d f=\frac{\left(\sigma^{2}{ }_{1} / n_{1}+\sigma^{2}{ }_{2} / n_{2}\right)^{2}}{\left(\sigma^{2}{ }_{1} / n_{1}\right)^{2} /\left(n_{1}-1\right)+\left(\sigma^{2}{ }_{2} / n_{2}\right) /\left(n_{2}-1\right)}
$$

\section{HASIL DAN PEMBAHASAN}

Dari hasil penelitian tentang penggunaan pakan lengkap berbasis tebon jagung terhadap kecernaan serat kasar dan BETN sapi FH dapat dilihat pada Tabel 3.

\section{Konsumsi Serat Kasar}

Dalam pakan berfungsi sebagai sumber energi utama, dimana sebagian besar selulosa dan hemisulosa dari serat dapat dicerna oleh mikroba yang terdapat dalam sistem pencernaannya dimana serat kasar digunakan sebagai sumber energi (Suprapto et al., 2013).

Rerata konsusmsi serat kasar (Tabel 3) memperlihatkan bahwa konsumsi serat kasar pada perlakuan Ra sebesar (2,07 kg/ekor/hari) dan konsusmi serat kasar pada perlakuan $\mathrm{Rb}$ sebesar $(2,10$ kg/ekor/hari). Hasil analisis uji $\mathrm{T}$ menunjukan bahwa perlakuan $\mathrm{Rb}$ berbeda tidak nyata $(\mathrm{P}>0,05)$ dengan perlakuan $\mathrm{Ra}$. Hal ini menunjukan bahwa penggunaan rumput raja sebanyak $35 \%$ tidak berpengaruh nyata terhadap jumlah konsumsi serat kasar. Hasil penelitian ini lebih rendah dari hasil penelitian Setianingtyas et al. (2014) yaitu (3,49 $3,84 \mathrm{~kg} / \mathrm{ekor} / \mathrm{hari}$ ) yang menggunakan imbangan hijauan dan konsentrat yang berbeda. Meningkatnya konsumsi pakan tergantung waktu tinggal pakan dalam rumen yang memberikan kesempatan mikrobia rumen mencerna pakan lebih lama, sebaliknya waktu tinggal pakan dalam rumen yang relatif singkat memberikan kesempatan mikrobia rumen dalam mencerna pakan juga akan singkat memungkinkan pakan cepat meninggalkan saluran pencernaan, sehingga konsumsi 
Tabel 3. Nilai Rerata Konsumsi dan Kecernaan Serat Kasar dan BETN

\begin{tabular}{lcc}
\hline \multicolumn{1}{c}{ Paramerer } & \multicolumn{2}{c}{ Perlakuan } \\
\cline { 2 - 3 } & $\mathrm{Ra}$ & $\mathrm{Rb}$ \\
\hline Konsumsi Serat Kasar (Kg/ekor/hari) & 2,07 & 2,10 \\
Konsumsi BETN (Kg/ekor/hari) & 3,36 & 3,46 \\
Kecernaan Serat Kasar (\%) & $70,31^{\mathrm{a}}$ & $78,15^{\mathrm{b}}$ \\
Kecernaan BETN (\%) & 87,97 & 90,28 \\
\hline
\end{tabular}

Keterangan : Superskrip yang berbeda pada baris yang sama menunjukan berbeda sangat nyata $(\mathrm{P}>0,01)$

pakan akan meningkat (Nuswantara et al., 2005).

\section{Konsumsi BETN}

Rerata konsumsi BETN (Tabel 3) memperlihatkan bahwa konsusmsi BETN pada perlakuan $\mathrm{Ra}(3,36 \mathrm{~kg} / \mathrm{ekor} / \mathrm{hari})$ sedangkan pada perlakuan $\mathrm{Rb}(3,46$ kg/ekor/hari). Hasil analisis uji $\mathrm{T}$ menunjukan bahwa perlakuan $\mathrm{Rb}$ memberikan pengaruh yang berbeda tidak nyata $(\mathrm{P}>0,05)$ dengan perlakuan Ra. Hal ini menunjukan bahwa penggunaan rumput raja 35\% tidak berpengaruh nyata terhadap konsumsi BETN. Rerata konsumsi BETN pada penelitian ini lebih rendah dari penelitian Purnamasari et al. (2019) yaitu $(5,62-5,73 \mathrm{~kg} / \mathrm{ekor} / \mathrm{hari})$ yang menggunakan rumput gajah, konsentrat dan suplemen Sauropus androgynous, Nigella sativa dan Sulfur proteinat.

BETN merupakan fraksi terlarut yang mudah terdegradasi dalam rumen
(Koten et al., 2014) hal ini berdampak pada tingkat konsumsi. Hadi et al. (2011) menyatakan bahwa pakan yang mengandung fraksi mudah larut dalam rumen akan mudah terdegradasi mikroba rumen yang akan meningkatkan konsumsi. Konsumsi BETN erat kaitannya dengan kecukupan energi. Pemenuhan kebutuhan energi diarahkan pada pemenuhan energi untuk hidup pokok, produksi dan reproduksi.

\section{Kecernaan Serat Kasar}

Rerata kecernaan serat kasar (Tabel 3) berdasarkan hasil analisis uji $T$ menunjukan kecernaan serat kasar pada perlakuan $\operatorname{Ra}(70,31 \%)$ berbeda sangat nyata $(\mathrm{P}<0,01)$ dengan perlakuan $\mathrm{Rb}$ $(78,15 \%)$. Nilai ini lebih tinggi dibandingkan dari yang dilaporkan Astuti et al. (2009) pada sapi perah awal laktasi yang diberi high quality feed supplement yang terdiri dari rumput raja, dedak halus 
dan konsentrat dimana perlakuan kontrol diberi rumput raja (18 kg/ekor/hari), dedak halus (5 kg/ekor/hari) dan konsentrat (8 $\mathrm{kg} / \mathrm{ekor} / \mathrm{hari}$ ), perlakuan subsitusi ditambahkan HQFS (300 gram/ekor/hari) tetapi konsentrat dikurangi sebanyak pemberian HQFS sedangkan perlakuan aditif ditambahkan HQFS tetapi tanpa mengurangi konsentrat yang mempunyai kecernaan serat kasar yaitu 32,56\% $36,94 \%$.

Tingginya kecernaan serat kasar pada perlakuan $\mathrm{Rb}$ dibandingkan perlakuan Ra diduga disebabkan karena kandungan serat kasar dalam pakan. Pada Tabel 2 terlihat bahwa perlakuan $\mathrm{Rb}$ angka serat kasar dalam pakan 25,93\% lebih rendah dibandingkan dengan perlakuan Ra yang serat kasarnya sekitar 26,16\%. Kecernaan serat kasar sangat tergantung dengan konsumsi serat dalam pakan. Semakin rendah kandungan serat kasar maka kecernaan serat kasar semakin meningkat.

\section{Kecernaan BETN}

Rerata kecernaan BETN (Tabel 3) memperlihatkan kecernaan BETN pada perlakuan $\mathrm{Ra}$ adalah $87,97 \%$ dan $\mathrm{Rb}$ 90,28\%. Analisis uji T menunjukan rerata kecernaan BETN pada kedua perlakuan memberikan pengaruh yang berbeda tidak nyata $(\mathrm{P}>0,05)$. Rerata kecernaan BETN pada penelitian ini lebih tinggi dari yang dilaporkan oleh Astuti et al. (2009) yaitu
70,69\%-75,30\% yang menggunakan high quality feed supplement. Tidak berpengaruhnya kedua perlakuan terhadap kecernaan BETN oleh karena jumlah pakan yang diberikan hampir sama baik dari jumlah maupun kandungan nutrisi.

\section{KESIMPULAN}

Berdasarkan hasil penelitian ini dapat disimpulkan bahwa pemberian pakan dengan perlakuan tebon jagung 35\% + rumput raja $35 \%$ + konsentrat $30 \%$ lebih baik dalam meningkatkan kecernaan serat kasar pada sapi Fries Holland.

\section{DAFTAR PUSTAKA}

Astuti, A, A. Agus, dan S.P.S. Budhi. 2009. Pengaruh penggunaan high quality feed suplement terhadap konsumsi dan kecernaan nutrien sapi perah awal laktasi. Buletin Peternakan 33 (2): 81-87.

Derrick, B., B. Russ, D. Toher, dan P. White. 2017. Test statistics for thecomparison of means for two samples that include both paired and independent observation. Journal of Modern Applied Statistical Methods 16(1): 137-157.

Dewi, O., N. N. Suryani, dan I.M. Mudita. 2020. Kecernaan bahan kering dan bahan organik secara in-vitro dari silase kombinasi batang pisang dengan kembang telang (Clitoria ternatea). Jurnal Peternakan Tropika 8(1): 60-73 
Direktorat Jenderal Peternakan dan Kesehatan Hewan. 2017. Statistik Peternakan dan Kesehatan Hewan. Livestock and Animal Health. Direktorat Jenderal Peternakan dan Kesehatan Hewan. Kementrian Pertanian.

Erna, W. dan Sarjiman, 2007. Budidaya hijauan pakan bersama tanaman pangan sebagai upaya penyediaan hijauan pakan di lahan sempit. Jurnal Peternakan dan Lingkungan 7: 134-141.

Hadi, R. F., Kustantinah, dan H. Hartadi. 2011. Kecernaan in sacco hijauan leguminosa dan hijauan leguminosa dan hijauan non leguminosa dalam rumen sapi perankan ongole. Buletin Peternakan 35(2): 79-85.

Koten, B. B., R. Wea, R. D. Soetrisno, N. Ngadiyono, B. Soewignyo. 2014. Konsumsi nutrien ternak kambing yang mendapatkan hijauan hasil tumpangsari arbila (Phaseolus lunatus) dengan sorgum sebgai $\mathrm{t}$ anaman sela pada jarak tanam arbila dan jumlah baris sorgum yang berbeda. Jurnal Ilmu Ternak 1(8): 38-45.

National Research Council. 2001. Nutrient Requirements of Diary Cattle.7th Ed. Washington National Academy Press.

Nuswantara, L.K., M. Soejono, R. Utomo, B.P. Widyobroto. 2005. Kecernaan nutrien ransum prekursor nitrogen dan energi tinggi pada sapi perah yang diberikan pakan basal jerami padi. Journal of the Indonesia Tropical Animal Agriculture 30(3): 172-178.

Purnamasari, N. Y., R. Hartanto, D. W. Harjanti. 2019. Konsumsi BETN dan Produksi Laktosa Susu Sapi
Perah Akibat Suplementasi Sauropus androgynous, Nigella Sativa dan Sulfur Proteinat. Prosiding dari Seminar Nasional Sains dan Entrepreneurship, Semarang.

Setianingtyas, R.W., Sujatmogo, T.H Suprayogi. 2014. Tampilan lemak dan bahan kering tanpa lemak pada susu sapi perah akibat pemberian ransum dengan imbangan hijauan dan konsentrat yang berbeda. Journal Animal Agricultur 3(2): 121-129.

Siswanto, D., B. Tulung, K. Maaruf, M. R. Waani, M. M Tindangen. 2016. Pengaruh pemberian rumput raja (Pennisetum purpupoides) dan tebon jagung terhadap kecernaan NDF dan ADF pada sapi PO pedet jantan. Jurnal Zootec 36(2): 379386.

Snedecor, G.W. dan W.G. Cochran. 1989. Statistical Methods, Eighth Edition, Iowa State University Press.

Soeharsono dan B. Sudaryanto. 2006. Tebon Jagung Sebagai Sumber Hijauan Pakan Ternak Strategis Di Lahan Kering Kabupaten Gunung Kidul. Prosiding. Lokakarya Nasional Jejaring Pengembangan Sistem Integrasi Jagung - sapi. 2006. Puslitbang Peternakan, Bogor. hlm. $136-141$.

Sondakh, E.H.B., M.R. Waani, J.A.D. Kalele, dan S.C. Rimbing. 2018. Evaluation of dry matter digestibility and organic matter of in vitro unsaturated fatty acid based ration of ruminant. International. $\mathbf{J}$. current adv. Res. 7(6): 13582-13584

Suprapto, H., F. M. Suhartati, dan T. Widiyastuti. 2013. Kecernaan serat 
kasar lemak kasar complete feed limbah rami dengan sumber protein berbeda pada kambing etawa lepas sapih. Jurnal Ilmiah Peternakan 1(3) 938-946.

Sutardi, T. 1981. Sapi Perah dan Pemberian Makanannya. Departemen Ilmu Makanan Ternak. Fakultas Peternakan Institut Pertanian Bogor. Bogor.

Tilman, A.D., H. Hartadi, S. Reksohadiprojo, S. Prawirokusumo dan S. Lebdosoekojo. 1989. Ilmu Makanan Ternak Dasar. Gadjah Mada University Press. Yogyakarta.

Tulung, Y.L.R., A.F. Pendong, B. Tulung. 2020. Evaluasi nilai biologis pakan lengkap berbasis tebon jagung dan rumput campuran terhadap kinerja produksi sapi Peranakan Ongole (PO). Zootec 40(1): 363 - 379 